\title{
YATVINGIANS IN THE GENESIS OF LITHUANIAN ANTI-TEUTONIC ORIENTATION*
}

\author{
Artūras Dubonis
}

ABSTRACT Scarce sources of the past of Sudovia (Süduva, Yatvingian lands) clearly reveal several episodes illustrating relations between the inhabitants of the area and the Lithuanians. They witness a much more complex paradigm of political communication between these groups than might be expected. When Mindaugas started to strengthen his rule in Lithuania, Lithuanian 'indifference' to the Yatvingians disappeared. At the beginning of the 1240s Mindaugas was becoming a genuine, rather than a nominal ruler of part of Sudovia, at least of its northeast. However, the strife, which began in 1246 between Mindaugas and the Yatvingians and lasted nearly the entire period of his rule, conditioned enormous concessions made by the king of Lithuania to the Teutonic Order in Sudovia. When the war against the Christians was taken over by Treniota in 1261, the struggle of the Yatvingians (and the Prussians) against the Crusaders became more intensive. These were good signs indicating the beginning Lithuania's support for the Yatvingians. The character of Treniota's relations with the Yatvingians conformed to the political situation and traditions established by his predecessors, first and foremost, by Mindaugas. All that weakened the support of the Lithuanian monarch to Yatvingian anti-Teutonic resistance, despite the relentless advance of the Order's military machine towards Lithuania's borders. The Lithuanian ruler did not maintain any political contacts with the Order, but being in its neighbourhood he acquired friends.

The conception about the by and large heroic and sometimes tragic struggle of the Baltic nations against the Teutonic Order enforcing an alien Christian religion ('the Teutonic-Baltic War'), summarised by the authors of Lietuviu karas su kryžiuočiais [Lithuanian war against the Crusaders], has turned into an undoubted canon in Lithuanian

* This article was prepared in the framework of the project 'Political, Ethnic, and Religious Confrontations in Lithuania in the Thirteenth - Fifteenth Centuries' funded by the Lithuanian State Foundation for Research and Studies 2006. 
historical self-consciousness. ${ }^{1}$ Doubtless, the position of the authors of that collective monograph was conditioned to a great extent by the desperate situation of the period - the Soviet occupation; and imperceptibly answers were sought to the question: why did the onetime powerful Lithuanian state gradually fall into decline and almost disappear from the map of the world (in this respect the Teutonic Order was indirectly responsible for the Soviet occupation of Lithuania as well). The authors made the Lithuanians, the strongest and the most active among the Balts, 'responsible' for all calamities. In the monograph they counted the strategic and tactical mistakes of the Lithuanian authorities and heaped reproaches on them. Thus, Rimantas Jasas feels obliged to say that

... possibly most important was the underestimation of the danger posed by the Crusaders (p. 120); ... the changes in the political situation in Rus' brought about by the Mongol-Tatar invasions activated the 'eastern' trend of the policy of Lithuanian feudal lords in the thirteenth and fourteenth centuries, and that became the principal trend, thus weakening their attention to the purely Lithuanian western lands. ... the Lithuanian stance in the war against its deadly enemy - the Livonian and Prussian Crusaders - was defensive rather than offensive ... (p. 121). The Prussians, even when supported by western Lithuanians, were too weak to resist such a force, and no serious aid came from Lithuania for various reasons after 1263 (the struggle for the throne after Mindaugas' murder, Vaišelga's pro-German policy and Traidenis' wars against Volhynia), although the expulsion of the Crusaders from the Prussian lands seemed very real at that time (p. 169).

Such were the anachronisms broken in by that time. Nevertheless, this collective study is still fascinating due to its motifs of unadulterated patriotism and disguised anti-Sovietism. Jasas attempted to identify the causes of the sad end of Yatvingian history:

... as regards the Crusader thrust into the Baltic lands further from the Vistula and Daugava, the Baltic losses can be accounted for by the absence of a united state and a limited and incidental support from a more militarily organised Lithuania. However, the Yatvingians were not far away somewhere behind the Vistula. They could be easily reached from Vilnius. Thus again a question arises: why did the people who were responsible for Lithuanian politics and the army fail to defend the Yatvingians from German occupation? (p. 176).

The historian reproached sadly grand duke Traidenis of Lithuania: 'The people of Prussia, Nadruva and Sudovia paid with their blood for all those major and minor achievements of the grand duke in the south [in Volhynia and Poland] (p. 176) ... Traidenis must have

${ }^{1}$ Lietuviu karas su kryžiuočiais, ed. J. Jurginis (Vilnius, 1964), p. 176. 
overlooked the fact that the front against the Prussian Crusaders in the west was becoming critical'. (p. 177).

The situation was assessed more optimistically by Romas Batūra; in his view, the struggle against the Teutonic Order contributed to the formation of the Lithuanian state of all Balts: 'the LithuanianYatvingian-Prussian collaboration was obvious already before the arrival of the Crusaders to the Vistula region'. Under Mindaugas' rule, Lithuania, depending on circumstances, actively supported the Prussian and Yatvingian-Sudovian struggle; in particular, the Lithuanians closely cooperated with the neighbouring Yatvingians against their common enemy, the Order. ${ }^{2}$

The classical authors of our historical scholarship found themselves confronted with a successful solution of the issue of 'common Lithuanian and Yatvingian wars against the Teutonic Order'. Controversial solutions of this problem were characteristic of the earlier researchers of the history of Lithuania, too. Thus, Henryk Paszkiewicz wrote that in the early thirteenth century the Lithuanians, Žemaitians and Yatvingians demonstrated an unbelievable internal integration of the Lithuanian state, ${ }^{3}$ and at the same time he somewhat contradicted himself, acknowledging that the Yatvingians could not be treated as a political entity. ${ }^{4}$ Therefore in Mindaugas' times the ties between the Lithuanians and the Yatvingians, although strengthening in the face of the growing outward danger, were still weak. ${ }^{5}$ Commenting on some facts of the history of the Yatvingians against the Christians, he sometimes exaggerated them as common Yatvingian-Lithuanian military expeditions.

Jan Powierski, a Polish scholar most dedicated to Yatvingian history, endeavoured to keep away (although not always consistently) from emotional generalisations of political and military aspects of the Yatvingian-Lithuanian contacts. ' ... the labour pains of the Lithuanian monarchy, the dispersal of its forces, inter-tribal strife, undervaluation of common Baltic interests by Lithuanian rulers, although quite

${ }^{2}$ R. Batūra, 'Petro Dusburgiečio kronika (Epocha, šaltiniai, tendencijos, reikšmė)'. Petras Dusburgietis, Prūsijos žemès kronika (PŽK) (Vilnius, 1985), pp. 13-16.

${ }^{3}$ H. Paszkiewicz, Jagiellonowie a Moskwa, vol. 1 (Warsaw, 1933), p. 43. Here the author speaks about common military actions of the Lithuanians, Žemaitians and Yatvingians. He was in need of this conclusion for his hypothesis of the establishment of the Lithuanian state before Mindaugas' times.

${ }^{4}$ Ibid., p. 89.

5 Ibid., p. 90. 
understandable in that era, prevented the Yatvingians from efficiently performing their role in the struggle against Crusader aggression and determined the ineptness and ineffectiveness of Lithuanian aid in that struggle'. ${ }^{6}$ This quotation shows that Powierski tried to base the possible unity of the Lithuanians, Yatvingians and other tribes by introducing the concept of the common Baltic interest, though he himself hardly believed in its consolidating power.

The groundwork for the research of the Yatvingian-Lithuanian relationship is quite significant and a separate study would be needed to its overview. In this work we consciously confined ourselves only to the main assumptions and conclusions by presenting them either in the text or in footnotes.

The concepts 'the Crusader-Baltic war', 'the formation of the Lithuanian state of all Balts', and 'the common Baltic interest' seriously handicap the knowledge of the contemporary political situation. They are alien to the thirteenth century, since those that are found in the sources are more characteristic of the accounts of the then states as multi-ethnic empires. They appeared when Mindaugas was strengthening his power. The Lithuanian king declared that he was going 'to unite for the Christian faith' the neighbouring pagan (Yatvingian, Žemaitian?) and infidel (i.e., Orthodox) lands (in 1251 and 1255). ${ }^{7}$ Severing connections with the Livonian (and also with the Teutonic) Order he hoped that the subjugated tribes of Livonia would surrender to his rule. ${ }^{8}$ In fact, the appearance of the Christian military orders in the Baltic lands left no choice for the pagans: their nobility could only choose to become subordinates of some particular lord (a Catholic German or Pole, an Orthodox Rus'ian or Lithuanian). In any case, that meant the loss of power (i.e., former freedom) and new duties and obligations. Therefore the territorial expression of the

${ }^{6}$ J. Powierski, 'Rola Jaćwieży w walce ludów bałtyjskich z agresją krzyżacką', Rocznik Białostocki, vol. 14, (1981), p. 111.

${ }^{7}$ The message of Pope Innocent IV of 17 July 1251 to the Lithuanian duke Mindaugas, see Mindaugo knyga: istorijos šaltiniai apie Lietuvos karaliu, ed. D. Antanavičius, D. Baronas, A. Dubonis, R. Petrauskas (Vilnius, 2005), p. 64 (no. 2); the message of Pope Innocent IV of 6 March 1255 to the Lithuanian duke Mindaugas, ibid, p. 78 (no. 21).

${ }^{8}$ Mindaugas reproached Treniota that the Latvians, Livs and the whole land of Livonia did not submit to his authority as had been promised, see the Lithuanian translation of parts of the Livonian Rhymed Chronicle (Eiliuotoji Livonijos kronika), trans. P. Žadeikis, R. Petrauskas, Mindaugo knyga, p. 290, 11. 6499-6510. 
programme of the Lithuanian ruler, 'the unifier of all Balts' was the agreement of the local nobility to yield to the authority of the Lithuanian ruler. Such an imperial interest of the Lithuanian monarch doubtless influenced the relations with the neighbouring pagans, including the Yatvingians.

Scarce sources of the past of Yatvingian lands clearly reveal several episodes illustrating their relations with the Lithuanians. They attest to a much more complex paradigm of the political communication between the Yatvingians and the Lithuanians than could have been expected.

Researchers have not yet arrived at a common assessment of the early cooperation between the Lithuanians and Yatvingians before the formation of the Lithuanian state. One must accept Edvardas Gudavičius' remark that we do not have data on the relations between the Lithuanians and the western Balts (with regard to the activity of Lithuanian warriors in the first decades of the thirteenth century). ${ }^{9}$ Consequently, alternative interpretations of available data are inevitable. The common interest of the Lithuanians and Yatvingians was first recorded in 1210 when they jointly attacked and harassed Volhynia. ${ }^{10}$ Lithuanian warriors appeared there as a new assault force, which may have been invited by the Yatvingians. Historical sources disclose an old conflict between Volhynia and the Yatvingians, since the latter were in the area of interest of Kiev and Chernigov dukes. That could be the first and the last joint campaign of the Lithuanians and Yatvingians. Later they will be seen together only in 1243-1244 in the army of Konrad of Mazovia in his efforts to gain the throne of the duchy of Cracow. ${ }^{11}$ However that happened under other political circumstances. The Lithuanian breakaway from the Yatvingians becomes

${ }^{9}$ E. Gudavičius, Mindaugas (Vilnius, 1998), p. 104.

${ }^{10}$ Halyts'ko-Volynskyi litopys. Doslidzhennia. Tekst. Komentar (HVL), ed. M.F. Kotliar (Kiev, 2002), pp. 78-79. ' ... litva zhe y iatviaz voevakhu, y povoevasha zhe Turysk' y okolo Komova oly y do Cher'vnia ... beda bo byst v' zemly V'lodimer'stii ot' voevania litov'skago i iatviazskago'. This publication of the HVL was prepared by Ukrainian historians on the basis of the Khlebnikov copy, of all known copies most closely resembling the lost protograph of the chronicle. It is dated according to M. Hrushevskyi, 'Khronologiia podii Halits'ko-Volyns'koi litopysy', Zapiski naukovogo tovaristva imeny Shevchenka, 3 (1901), pp. 9-10, 62.

${ }^{11}$ V.T. Pashuto, Obrazovanie Litovskogo gosudarstva (Moscow, 1956), pp. 1316. In his research of the diplomacy of Halicz Volhynia Kotliar is not original - he makes use of Pashuto's groundwork, see Narysy z istorii dyplomatii Ukrainy, ed. V.A. Smolii (Kiev, 2001), p. 69. 
obvious after the conclusion of the treaty between Lithuanian dukes and the duke of Volhynia Danilo and his mother in $1219 .{ }^{12}$ Having opted for the Lithuanians, Danilo used them for his political purposes, ${ }^{13}$ including the restriction of the relations between the Lithuanians and Yatvingians possibly even in the third and fourth decades of the thirteenth century. ${ }^{14}$

On the other hand, it is argued that at that time - in the first half of the thirteenth century - the Lithuanians and the Yatvingians were allies. ${ }^{15}$ Commenting on the 1219 treaty some historians perceive grand Lithuanian-Žemaitian-Yatvingian coalitions; ${ }^{16}$ and the coalition of the Prussian tribes (the Yatvingians among them being the strongest) and the Lithuanians formed by the duke Danilo. ${ }^{17} \mathrm{~A}$ danger arose from the crusade called in 1218, and Lithuania and Žemaitija concluded a treaty with Volhynia; there were attempts to defend Prussia; and joint Lithuanian and Yatvingian forces attacked Poland. ${ }^{18}$. The argumentation of the cited scholars is complicated, and based on unreliable sources. Thus, untrustworthy data of the Hustyn copy of the Halicz-Volhynia chronicle are often 'corrected' by the data of the notorious printed Poland and GDL annals of the sixteenth century. Using an old methodology, Polish investigators attributed the Yatvingians to the Prussians. Quoting the 1219 treaty from the HaliczVolhynian chronicle, Batūra inadequately interprets its commentary, informing that the Lithuanians attacked the Cracow duke Leszek the White, the enemy and rival of the duke of Volhynia, and making no mention of the Yatvingians: 'Ляхомь же не престающимь пакостящимъ, и приведе на ня литву: и воеваша ляхи и много убійства сътвориша в нихъ'. ${ }^{19}$

12 HVL, p. 84.

${ }^{13}$ It was noticed that Danilo could target the Prussian attack of 1217 against the Mazovian duke Konrad, because the latter supported Danilo's enemy Leszek I the White, see B. Włodarski, Polska i Ruś 1194-1340 (Warsaw, 1966), p. 72.

${ }^{14}$ A. Dubonis, 'Voluinietiškos Lietuvos užsienio politikos krypties formavimasis (iki Mindaugo mirties 1263 m.)', Lituanistica, 4, 2005, pp. 2-4.

15 Powierski, ‘Rola Jaćwieży’ p. 90.

16 Paszkiewicz, Jagiellonowie a Moskwa, p. 43. However, this scholar relied too heavily on the Hustyn copy of the HVL.

${ }^{17}$ B. Włodarski, 'Problem Jaćwiński w stosunkach polsko-ruskich', Zapiski Historyczne, 24, zesz. 2-3 (1958-1959), pp. 28-29; Włodarski, Polska i Ruś, pp. 166-167.

18 Batūra, 'Petro Dusburgiečio kronika', pp. 13-14.

19 HVL, p. 84; Pashuto, Obrazovanie, p. 374. In 1220 the Lithuanians attacked the duke of Chernigov. Unlike the Poles, Pashuto considered the Yatvingians more dependable on the Lithuanians; cf. ibid. pp. 31-32. 
These alternatives, offering differing conclusions, present a serious problem awaiting its solution. However, in actual fact, there are no concrete data attesting the cooperation between the Lithuanians and the Yatvingians before 1243. Until the early 1240s Mindaugas was at peace with Duke Danilo of Volhynia (and with Halicz periodically until 1245) and did not take an interest in the Yatvingian lands. Later events show that the political relations between Mindaugas and Danilo conditioned Lithuania's attention to this area.

Data indicating new tendencies in the contacts between the Lithuanians and the Yatvingians appeared in the sources when Mindaugas started to strengthen his rule in Lithuania. Gudavičius investigated the information contained in the act relating to the boundaries of new Prussian bishoprics established by Bishop William of Modena on 29 July 1243 - at that time Northern Sudovia could recognise Mindaugas' nominal authority. ${ }^{20}$ This is also supported by the data (not quite reliable) about Lithuanian and Yatvingian support for Konrad of Mazovia on his struggle for the Cracow throne in 1243-1244. ${ }^{21}$ At the same time, the Lithuanians are also mentioned in the sources relating to the wars of Duke Śwętopelk of Pomerania and the Prussians against the Teutonic Order. Lithuanian and Prussian attacks against the Order are also reported in a series of bulls of Pope Innocent IV to Śwętopelk, Archbishop Fulk of Gniezno and the Master of the Order on 1 February $1245 .{ }^{22}$ In recent scholarship it has been proved that Lithuanian support could be only indirect. The possibility of Lithuanian participation in the Prussian and Yatvingian (Sudovian) campaigns against the land of Kulm in 1243-1244 is ruled

${ }^{20}$ E. Gudavičius, Kryžiaus karai Pabaltijyje ir Lietuva (Vilnius, 1989), p. 79 (the related source is indicated there, too).

${ }^{21}$ Joannis Dlugosii Annales seu Cronicae incliti regni Poloniae, lib. 7, 8 (Warsaw, 1975), p. 32. In 1241 Konrad of Mazovia led his army - in it ranks '... exercitu ... ex auxiliariis Pruthenis et Lithwanis ...’; ibid., pp. 41-42: in the army of Konrad of Mazovia ' ... Cunradus Mazowie dux excitus, versus Cracowiam, stipatus gentibus multis, Mazowitis, Lithwanis, Iatwingis et ceteris barbaris processit'; ibid., p. 46: in 1244 his army marched against the duke of Cracow Boleslaus the Shameful '... Lithwanos, Pruthenos et Iaczwingos contra nepotem suum Boleslaum Pudicum Cracowiensem ducem ... prece et precio subornat'. The doubts of historians concerning the participation of the Lithuanians and other Balts in these campaigns are presented by G. Błaszczyk, Dzieje stosunków polsko-litewskich od czasów najdawniejszych do wspótczesności, t. 1: Trudne poczatki (Poznań, 1998), pp. 36-37.

${ }^{22}$ Preußisches Urkundenbuch / Politische Abteilung, Bd. 1, H. 1, eds R. Philippi, K. P. Wölky (henceforth PUB-1), (Königsberg, 1882), nos 160-162; Mindaugo knyga, pp. 54-55 (Nr. 20-22); Lietuviu karas su kryžiuočiais, pp. 133-134. 
out altogether ${ }^{23}$ - on 15 June 1243 the German Knights were defeated by the Prussians and the Sudovians in the fens at Renze. ${ }^{24}$ However, either the Lithuanian and Žemaitian raid, led by Mindaugas, to recapture Amboten (Anboten) castle in Curonia from the Livonian Order late in 1244 or some other earlier Mindaugas' activities, coordinated with Śwętopelk, triggered off a response of the Teutonic Order and the pope in the bulls of 1 February $1245 . .^{25}$ In these confrontations the Yatvingians were Prussian allies and somehow found themselves between the latter and the Lithuanians. Therefore Powierski conjectured cautiously that the Yatvingians could mediate the Lithuanian accession to Śwętopelk. ${ }^{26}$ Thus the Lithuanian military and political interests in the southwest could be directed against the Teutonic Order. ${ }^{27}$

At that time, when Lithuanian 'indifference' to the Yatvingians vanished and signs of the enmity towards the Teutonic Order appeared, the Lithuanian duke Mindaugas was at odds with his old friend Duke Danilo. Between 1241 and the first half of 1245 Mindaugas brought under his control Rus'ian towns on the upper reaches of the Nemunas (Novogrudok, Slonim, and Volkovysk), which formerly were in the sphere of Volhynia's influence. ${ }^{28}$ That time Danilo had to yield, since he was engaged in the preparations for the war for Halicz, his patrimony. He even made peace with Mindaugas and asked him for military aid on the eve of his victory in the battle of Yaroslav (Jarosław) on 17 August $1245 .{ }^{29}$ That year marked a radical change in the relations between the Lithuanians and the Yatvingians. The Lithuanians alone, without the Yatvingians, came to help Konrad of Mazovia in

${ }^{23}$ Gudavičius, Kryžiaus karai, pp. 72-76.

${ }^{24}$ Batūra, 'Petro Dusburgiečio kronika', p. 372.

${ }^{25}$ Gudavičius, Kryžiaus karai, pp. 83-85; Idem, Mindaugas, p. 207.

26 Powierski, 'Rola Jaćwieży' p. 93.

${ }^{27}$ It is noteworthy that Konrad of Mazovia and his son duke of Kujawy Casimir as allies of the Teutonic Order supported the Order in its struggle against the Prussians. Cf. B. Włodarski, Rywalizacja o ziemie pruskie w połowie XIII wieku (Toruń, 1958), pp. 20-25; Gudavičius, Kryžiaus karai, p. 78. Consequently, the Lithuanian backing of the Teutonic ally and their enemy would be most odd. That could be treated as a consequence of the policy of warbands (see Gudavičius, Mindaugas, p. 101), when loosely controlled Lithuanian and Žemaitian conflicting forces, acting independently on different fronts, substantially benefited Mindaugas.

${ }^{28}$ Dubonis, 'Voluinietiškos Lietuvos ...', pp. 5-6.

${ }^{29}$ HVL, p. 107: ‘... Данило же и Василко посласта в Литву, помощи просяща, и послана бысть оть Миньдога помощь' 
his struggle for Cracow in $1246 .{ }^{30}$ Konrad was interested not only in the throne of Cracow; he also felt safer on the Yatvingian front, summoning the duke of Volhynia, Vasilko Romanovich, against this enemy in January-February that year. ${ }^{31}$ However, the campaign came to nothing due to severe colds.

The troops of the duke Danilo of Halicz-Volhynia, his brother Vasilko, Duke Siemowit of Mazovia, son of Konrad, who died in 1247, and Duke Bolesław of Cracow attacked the Yatvingians. Though supported by the Prussians, Bartians, and Varmians, they suffered crushing defeats. ${ }^{32}$ That was the beginning of the conquest of the Yatvingians. Some researchers detect a Mazovian-Halicz-VolhynianLithuanian union, directed against the Yatvingians. ${ }^{33}$ These events were closely followed by Duke Casimir (Konrad's son, Siemowit's elder brother) of Kujawy - until that time he was an ally of the Teutonic Order. He was also interested in getting a part of the Yatvingian lands. Therefore the relations between Casimir and the Order began to deteriorate in the latter half of $1248 .{ }^{34}$ Mindaugas and his south-western neighbours exerted pressure on the Yatvingians from the east and north, thus seeking to annex them to Lithuania or to increase his influence. ${ }^{35}$ It is credible that in 1249 Vygantas successfully exploited tense relations between Mindaugas and the Yatvingians and coaxed them into a coalition against the Lithuanian monarch. This assumption is confirmed by the information found in the Halicz-Volhynian chronicle suggesting that Danilo and his allies

${ }^{30}$ Joannis Dlugosii Annales, p. 55: In 1246 Konrad of Mazovia, on whose side there are Lithuanians, again attacks Bolesław and reaches victory at Zaryszin '... terras et principatus nepotis sui Boleslai Pudici Cracoviensis ducis et suarum terrarum et Lithwanicarum stipatus auxilio invadit'. See also Mindaugo knyga, pp. 138-139 (no. 7).

31 HVL, p. 110; the year 1246 is indicated according to Hrushevs'kyi, 'Khronol'ogiia', p. 33.

${ }^{32}$ HVL, pp. 110-111.

${ }^{33}$ Powierski, 'Rola Jaćwieży', p. 94; Błaszczyk, Dzieje stosunków, p. 27; Gudavičius, Mindangas, p. 210. Włodarski, however, maintains that at that time Danilo and Mindaugas, being rivals for Black Rus', could hardly negotiate on joint actions; cf. Włodarski, 'Problem Jaćwiński', p. 31. This territorial dispute had been solved between Mindaugas and Danilo on the eve of the battle of Yaroslav, see footnote 29).

34 Włodarski, Rywalizacja o ziemie pruskie, pp. 35-36; Powierski, 'Rola Jaćwieży', pp. 94-95.

35 The 1251 documents of Pope Innocent IV on Mindaugas' baptism specifically emphasise his task to christianise the neighbouring pagans; cf. Mindaugo knyga, pp. 64-68; Gudavičius, Mindaugas, pp. 203-204. 
Lithuanian dukes were interested in directing against Mindaugas the pagans (more dependant on him, including the Žemaitians): Данилу же и Василку пославшима Выкиньта въ Ятвязе и въ Жемойть, къ Немчемь въ Ригу: и Выкинть же убеді я сребромъ и даръми многыми ятвязе и поль Жемойти. ${ }^{36}$ Thus, about the middle of the thirteenth century Mindaugas was becoming a real rather than nominal ruler of a part of Sudovia (Yatvingia); at the same time he had to restrict his strivings taking into account duke Danilo's interests.

It was also one of the early signs that the Yatvingian territory, surrounded by the areas of interest of different monarchs, began to diminish. The Lithuanians and Mindaugas, like the Poles or the Rus'ians, was eager to tear off a piece of the Yatvingian territory for himself. However, his chances in these cruel partitions were the slimmest.

To Danilo's annoyance, in 1252 Mindaugas 'bought out' the Žemaitians from the coalition of his enemies, but the Yatvingians remained hostile to him: Тогда же Тевтивиль прибежа къ Данилу изъ Жемойти и ятвязе и рече, яко Миндовгь убеди я сребромь многомъ; Данилу же гневь имеющю на ня. Traditionally this sentence is translated incorrectly as 'the Žemaitians and the Yatvingians were bought over'. Actually Тевтивиль and ятвязе are subjects and their predicate is прибежа, and the whole sentence should be translated as 'Tautvilas with the Yatvingians fled Žemaitija because Mindaugas bought the Žemaitians over (persuaded them into) with silver' ${ }^{37}$ The Yatvingians were clearly slipping from Mindaugas' hands, and there was little chance of his introducing his rule there. The military and political positions of Duke Danilo of Halicz-Volhynia, his brother Vasilko, the Mazovian duke, Siemowit, and doubtless of the Teutonic Order (including its Livonian branch) were much better. The latter, at that time, had waged a major campaign primarily for its formal rights in Sudovia.

Late in 1253 Danilo and his son-in-law Siemowit invaded the territory of the southern Yatvingians. Danilo participated in the campaign as king - he was newly crowned by the pope's legate in Dorohichin. The royal army overran the area of Rajgród (Steikintas'

36 HVL, p. 112.

${ }^{37}$ HVL, pp. 113-114; the year 1252 is indicated according to Hrushevs'kyi, 'Khronol'ogiia', p. 35. I wish to acknowledge my debt to Tetiana Vilkul for her assistance in the translation. Formerly interpreting the structure of the sentence traditionally I also considered that Mindaugas 'bought over' the Žemaitians from a hostile coalition, cf. Dubonis, 'Voluinietiškos Lietuvos ...', pp. 8-9. The revised translation makes the causes of Mindaugas' tense relations with the Yatvingians clearer. 
lands ?). ${ }^{38}$ The other part of the Yatvingian territory was hastily dealt with by the Order, since Duke Casimir of Kujawy was going to engage in peaceful Christianisation of pagans with the consent of the pope. The Livonian Order, however, took large-scale precautionary measures against him. As soon as Pope Innocent IV authorised Casimir to foster (to rule over) the pagans of Polexia (Yatvingians) and Galens (Galindians) by the bull of 19 May 1253, because they themselves expressed their wish to be baptised, ${ }^{39}$ in July of the same year Mindaugas donated the Livonian Order a half of the territory of Dainava and of other Yatvingians for the Order's support in the struggle against the enemies of his kingdom and the Christian faith. The Pope endorsed the donation on 21 August. ${ }^{40}$ Clearly exploiting the situation when Mindaugas was at war with Halicz-Volhynia and in conflict with the Yatvingians, the Order obtained Mindaugas' promise not to intervene in Yatvingian matters. Such should be the interpretation of Mindaugas' attitude to the lands the subordination of which was far from clear. The Order brought Casimir to its terms, too. In the autumn of 1254 the Master of the Teutonic Order, and Danilo, officially titled as 'the first Rus'ian king', along with Duke Siemowit of Mazovia concluded the treaty of Raciąż according to which the latter two were allotted a third (a sixth each) of the Yatvingian lands, while the rest supposedly went to the Order. ${ }^{41}$ In Włodarski's opinion, the treaty was aimed at Casimir, since it foresaw not only mutual assistance in the struggle against the pagan Yatvingians but also against all others, not pagans. ${ }^{42}$ Late in the same year the grand master and Casimir met in Inowrocław and agreed on mutual concessions, and the latter renounced all his rights relating to the Yatvingians and the Galindians, given to him by the Pope. ${ }^{43}$ The Polish part of the Order's interests in Sudovia was settled. pp. 36-37.

${ }^{38}$ HVL, p. 116. The date is indicated according to Hrushevs'kyi, 'Khronol'ogiia',

${ }^{39}$ PUB-1, nos 267-368; Włodarski, Rywalizacja o ziemie pruskie, pp. 38-39.

${ }^{40}$ On King Mindaugas' acts of the donation of a part of lands in Žemaitija and Dainava and their authentication by the Pope, see Mindaugo knyga, pp. 69-71 (nos 9-10). Judging by the Pope's authentication of 21 August 1253, King Mindaugas donated lands for a free choice of a bishop and the guarantees of the establishment of an ecclesiastical province subordinate to Rome; see also pp. 71-72 (nos 11).

41 PUB-1, no. 298; Błaszczyk, Dzieje stosunków, pp. 28-29.

${ }^{42}$ Włodarski, Rywalizacja o ziemie pruskie, pp. 42-43; A. Szweda, 'Polityka Siemowita I Mazowieckiego wobec Zakonu Krzyżackiego po 1254 roku', Rocznik Grudziqdzki, 15 (2003), p. 23.

${ }^{43}$ PUB-1, no. 303; Włodarski, Rywalizacja o ziemie pruskie, p. 45; Szweda, 'Polityka Siemowita', p. 23-24. 
It can be conjectured that the leaders of the Teutonic Order participated in the resolution of one more conflict. As Christian rulers, Mindaugas and Danilo had to live in peace. However, in the military and political agenda of the Rus'ian king the number one priority was the conquest of one sixth of the Yatvingian area with the help of the Teutonic Order and the Mazovians. ${ }^{44}$ The conflict between Mindaugas and Danilo was undesirable - peace between them was more useful for the Order - Mindaugas could help Danilo and Siemowit to conquer the Yatvingians. At the end of 1254 the first Rus'ian king, Danilo, became the kin of the Lithuanian king, Mindaugas, who made some territorial concessions. A very interesting clause of the treaty was the handover of Novogrudok to Danilo's son Roman; it was the most important town of the Rus'ian territory annexed by the Lithuanians in the upper reaches of the Nemunas between 1241 and 1245. Mindaugas, nevertheless, remained the ruler of the entire territory. ${ }^{45}$ In the winter of 1254-1255 a major raid was conducted against the third part of the Yatvingian lands which went to the Rus'ians and the Mazovians in the Raciąż partition. The first Rus'ian king Danilo, his sons Lev and minor Shvarno, the king's brother Vasylko, the Mazovian duke, Siemowit, (or only Mazovian soldiers ${ }^{46}$ ). Duke Bolesław the Shameful of Cracow sent his soldiers from Sandomierz and Cracow. Roman, lieutenant of the lands of Novogrudok which belonged to Mindaugas also took part in the campaign with his troops. ${ }^{47}$ That was the aid sent from Lithuania, which could include even mixed Rus'ianLithuanian forces. ${ }^{48}$ In the face of aggression from all their neighbours,

44 Paszkiewicz, Jagiellonowie a Moskwa, pp. 81; Włodarski, Rywalizacja o ziemie pruskie, pp. 31-32.

${ }^{45}$ Gudavičius, Mindaugas, pp. 241-242; Dubonis, 'Voluinietiškos Lietuvos ...', p. 7. The year 1254 is indicated according to Hrushevs'kyi, 'Khronol'ogiia', p. 38.

${ }^{46}$ Siemnovit's participation is dubious. At the end of 1254 he was imprisoned by his elder brother, Casimir for several months for his stance on the Yatvingian question and friendship with the Order; cf. Włodarski, Rywalizacja o ziemie pruskie, pp. 43-44; Szweda, 'Polityka Siemowita', p. 22-24. Therefore these and some other Polish scholars date the raid into Yatvingia a year later - 1455-1256. But the date 1254-1255 is correct, cf. Hrushevs'kyi, 'Khronol'ogiia', pp. 38-39. The publisher of the Khlebnikov copy of the HVL Kotliar maintains that Siemowit did not participate in the raid, while a later editor of the HVL, aware that the duke always supported Danilo against the pagans, added the duke of Mazovia in the list of the participants, cf. HVL, pp. 290-291.

${ }^{47}$ HVL, p. 117.

${ }^{48}$ Here the scheme of the presentation used by the editor of the HVL resembles the description of the attack of Vozviagl, organised by Mindaugas and 
the southern Yatvingians agreed to pay tribute to Danilo and let him build castles in their territory. ${ }^{49}$ They also made a similar commitment to the Mazovians. ${ }^{50}$

Regrettably, a comparatively small and poor Yatvingian territory was a point of contention for its powerful neighbours, and a predomination of one of them caused danger for the others. That was a mark of an important strategic situation of that area. King Mindaugas was isolated from the Yatvingians by the discord of 1246 between them and also by a coordinated policy of the more experienced political agents, such as the Teutonic Order, Danilo and their allies. Danilo simply annexed areas that were only loosely attached to the nucleus of statehood in southern Lithuania. Eventually, helping to wage wars in southern Jotuva (Yatvingia), Mindaugas indirectly became an associate of the Raciąż agreements.

The Teutonic Order closely guarded its rights over the Yatvingians. Its authorities managed once more to reject the claims of Duke Casimir of Kujawia to some Yatvingian lands, although in 1256 in Rome he renewed his Christianisation efforts and was granted the right to protect the peacefully baptised pagans. On 4 August 1257 in Włocławek Casimir and his brother Siemowit renounced partially their right to some pagan lands in favour of the Order. ${ }^{51}$ On 7 August

Danilo, see HVL, pp. 120-121. Mindaugas behaves like an outright ruler of Novogrudok and sends Roman and his troops to Danilo: Приилю к тебе Романа $u$ новьгородии. Then follows the explanation why the aid did not reach Danilo: Данило ... жда вести оть Романа и литвы. Thus, Roman commands both Novogrudok and Lithuanian troops. Besides, Roman has his own Rus'ian following, which he kept by himself. Meanwhile he let the others, firstly the Lithuanians, go home: ... Романъ еха по отии, поемь съ собою мало людій, а прочіа пусти домов. Instead of going home, the Lithuanians started pillaging the environs of Lutsk and were defeated.

${ }^{49}$ HVL, p. 119.

${ }^{50}$ H. Łowmiański, Studja nad poczatkami społeczeństwa i państwa litewskiego, vol. 2 (Vilnius, 1932), p. 254; Szweda, 'Polityka Siemowita', p. 25.

${ }^{51}$ Włodarski, Rywalizacja o ziemie pruskie, pp. 48-49, 51. In addition to the Yatvingians, Casimir was interested in the Lithuanians. He was one of those Polish dukes who at the beginning of 1257 obtained the pope's bulls to lead a crusade against the Lithuanians and the Yatvingians, see ibid., pp. 48-49; Gudavičius, Kryžiaus karai, pp. 120-122. However after half a year the Teutonic Order secured more favourable bulls than the Poles, see ibid., pp. 122-123. The bulls refer to Lithuanian who were not Mindaugas' subjects. Now it has been proved definitely that they were the people living in a peripheral territory between Sudovia and Poland loosely attached to the nucleus of the kingdom, see ibid., p. 121. Not being familiar with this work of Gudavičius, Polish researchers also came to similar conclusions, cf. Szweda, 'Polityka Siemowita', pp. 25-26. 
1259 King Mindaugas again confirmed the assignment of Dainava (the Yatvingians) and some other lands to the Livonian Order, keeping some territories for himself. ${ }^{52}$ Lands were donated to the Order for its assistance to the king and his successors in their struggles against the enemies of faith, who used to attack the border regions of the kingdom. Interestingly, the king had to confirm repeatedly the donation of the already donated part of Dainava and to add the rest of it, by indicating that Dainava in Lithuania is the same Yatvingians ...Denowe tota, quam etiam quidam Jetwesen vocant ... ${ }^{53}$ The use of specified terms attests to the sensitivity of the Yatvingian issue, and Lithuanian support was a major argument of the Crusaders in their debates with the Poles or in the discussions with the pope concerning the Yatvingians.

Mindaugas' concessions to the Order and the latter's concerns were undoubtedly conditioned by a blow delivered by the Tatars led by Burundai in the winter of $1258-1259 .{ }^{54}$ A new political situation arose in this area when the Tatars broke the military and political power of the first Rus'ian king Danilo. ${ }^{55}$ Danilo's difficult situation raised the issue of the Yatvingians under his rule. ${ }^{56}$ Again the Order turned out to be the most active. In addition to the promise of the Lithuanian ruler of 7 August 1259 not to interfere in Yatvingian matters, in 1260 it secured the papal permission to annex Rus'ian lands, including those occupied by the Tatars. ${ }^{57}$ The Crusaders signed

${ }^{52}$ King Mindaugas' donation act of the lands of Dainava, Skalva and Žemaitija to the master of the Livonian Order and his brothers, see Preußisches Urkundenbuch / Politische Abteilung, Bd. 1, H. 2 (henceforth - PUB-2), ed. A. Seraphim, (Königsberg, 1909), no. 79. The localization of the Yatvingian territory is not the aim of this article.

${ }^{53}$ PUB-2, no. 79, p. 70.

${ }^{54}$ Batūra, Lietuva tautu kovoje prieš Aukso Ordq (Vilnius, 1975), pp. 125144; Gudavičius, Mindaugas, pp. 260-262.

${ }^{55}$ Hrushevskyi, Istoriia Ukraïny-Rusy, vol. 3 (Lvov, 1905), pp. 89-90; Pashuto, Obrazovanie, pp. 381-382; V.L. Egorov, Istoricheskaia geografiia Zolotoi Ordy v XIII-XIV vv. (Moscow, 1985), pp. 188-189; A. Szweda, 'Polityka Siemowita' p. 30. Some investigators consider that Burundai's blow was not crucial for Danilo, cf. O.B. Holovko, Korona Danyla Halits'koho. Volyn' i Haliczina v derzhavnopolitychnomu rozvytku Tsentral'no-Skhidnoi Europy rann'oho ta klassichnoho seredn'ovichchia (Kiev, 2006), pp. 352-354.

56 Włodarski, 'Problem Jaćwiński', p. 35.

${ }^{57}$ Concerning the source of the quotation and an accurate assessment of the political situation, see Gudavičius, Mindaugas, p. 261, note 2235. The Crusaders probably prevented Mindaugas from taking revenge on Danilo for his support of Burundai against Lithuania. Mindaugas sent his forces to Volhynia in 1262 only after his reversion to paganism, see Dubonis, 'Voluinietiškos Lietuvos ...', pp. 9-10. 
a new agreement with one more participant of the treaty of Raciąż, Siemovit of Mazovia. The treaty was concluded between him and the land master of the Teutonic Order, Hartmund Grumbach, in Troszyn on 15 June 1260, and Mazovia was again granted the right to one sixth of the Yatvingian land, and support was promised for Siemovit in his conquest of the Yatvingians and in the fight against other, most probably Žemaitian, enemies. ${ }^{58}$

The concerns of the Order were reasonable, since dangers to its existence were real. The restriction of the chances of Mindaugas and Casimir of conducting a more independent foreign policy and their alienation from the Yatvingian affairs led to their closer cooperation. Approximately before the spring of 1262 or maybe even in 1261, Casimir entered into a short-term treaty with the pagan Lithuanians (King Mindaugas) and the Prussians, who had risen in revolt. ${ }^{59}$ It is difficult to say who the mediators in the contacts between the representatives of Mindaugas and Casimir were. The activities of the Yatvingians alone or even of the insurgent Prussians, Galindians, and Yatvingians are detected. ${ }^{60}$ However, this is only pure speculation in order to strengthen the conception of the common Baltic interest, as there too many contributors in this subtle sphere. Taking into consideration the commitments of the participants of the treaty of Troszyn, the Žemaitians could also be added to the mediators. In this context, an influential figure doubtless acting behind their backs was Treniota, the energetic nephew of Mindaugas. He sought to fight against the Christians and envisioned the submission of all pagan tribes to the Lithuanian monarch as the leader of this struggle. He was concerned with the Prussian uprising to the southwest of Lithuania. He could be an initiator of the political rapprochement between the Lithuanians and Casimir, and that is attested by his actions. In 1262 a huge army of the Lithuanians and other pagans led by him invaded the Vistula area (Mazovia, Pomesania, and Kulm):

58 PUB-2, no. 104; Włodarski, Rywalizacja o ziemie pruskie, p. 57; Szweda, 'Polityka Siemowita', p. 33.

59 Włodarski, Rywalizacja o ziemie pruskie, pp. 61-63; J. Powierski, 'Stanowisko polityczne książąt polskich wobec ludów bałtyjskich i Zakonu Krzyżackiego w okresie nasilenia najazdów litewskich (1261-1263)', Acta BalticoSlavica, 15 (1983), pp. 35-36; Gudavičius, Kryžiaus karai, p. 140; Błaszczyk, Dzieje stosunków, pp. 30-31.

${ }^{60}$ Włodarski, Rywalizacja o ziemie pruskie, p. 63; Powierski, 'Rola Jaćwieży', p. 102 . 
Trinota filius regis Lethowinorum assumptis sibi pluribus aliis gentibus ... ad prelium congregavit ... ${ }^{61}$ Extant sources illustrate best the devastation of Mazovia and the death of its duke and ally of the Order, Siemowit. ${ }^{62}$ The Yatvingians must have been among the gentes, since the shortest way to the area of attack led namely through their lands (the route through Halicz-Volhynia was unacceptable since Mindaugas was feuding with their dukes). Under Treniota's rule Prussian, Yatvingian and Lithuanian forces attacked Wehlau castle in Samland early in $1264 .{ }^{63}$

When Treniota took the initiative in the war against the Christians the military activities of the Yatvingians (and the Prussians) increased. According to historical sources at least four raids were launched against Prussia, Kulm and Torun in 1262 and $1263 .{ }^{64}$ When Yatvingian affairs became a priority for Lithuanian foreign policy makers, the Yatvingian war leader Skomantas, subsequently known for his proLithuanian attitudes, came to the fore. ${ }^{65}$ These were serious signs indicating the beginning of Lithuanian support for the Yatvingians. However, the fact that the Yatvingians and the Prussians alone carried out four raids against the Order in 1262-1263 and only two raids with the Lithuanians shows that the latter did not always come to their aid. The cooperation between the Lithuanians and the Yatvingians until Treniota's death in 1264 is evident; however, the popular historiographical statement about the Yatvingians joining with the Lithuanian monarchy of Mindaugas (with the usual reservation of $a$ part of Yatvingians) is not sufficiently grounded. ${ }^{66}$

${ }^{61}$ Petrus de Dusburg, Cronica terre Prussie, Scriptores Rerum Prussicarum (henceforth - PD), vol. 1, eds T. Hirsch, M. Töppen, E. Strehlke (Leipzig, 1861), pp. 125-126 (§ 160(155)); PŽK, pp. 182, 396 (Batūra's comments); Gudavičius, 'Dèl lietuvių antpuolių Mozūrijoje XIII a. 7-ojo dešimtmečio pradžioje', Lietuva ir jos kaimynai: nuo normanu iki Napoleono / Prof. Broniaus Dundulio atminimui, ed. I. Valikonytė et al. (Vilnius, 2001), pp. 82-94.

${ }^{62}$ Dubonis, 'Meilè ir politika: Traidenis tekina dukrą', Darbai ir dienos, 44 (2005), p. 31.

${ }^{63}$ PD, p. 112 (§ 122(117)); Gudavičius, Kryžiaus karai, pp. 145-146, 148-149.

${ }^{64}$ PD, p. $110(\S 116(111))$, p. 125 (§ 158-159(152-153), p. 126 (§ 162(157)), p. 127 (§ 164(159)); Gudavičius, Kryžiaus karai, p. 154.

${ }^{65}$ A. Kamiński, Jaćwież. Terytorium, Ludność, Stosunki gospodarcze i spoleczne (Łódż, 1953), pp. 176-177; Lietuviu karas su kryžiuočiais, p. 173.

${ }^{66}$ Paszkiewicz, Jagiellonowie a Moskwa, pp. 90, 100; Włodarski, 'Problem Jaćwiński', p. 33; Powierski, 'Rola Jaćwieży', p. 102; Batūra, 'Petro Dusburgiečio kronika', p. 15. 
The historical sources of the second half of the thirteenth century increasingly witness the lack of unity among the Yatvingians and tendencies of their splitting. The duke of Cracow Bolesław the Shameful seems to have dealt a crushing blow to the Yatvingians and that is emphasised by many researchers. ${ }^{67}$ Nevertheless, it was not an end of Yatvingian history since their armed forces continued to fight against the Christians. In 1269, together with the Lithuanians, they participated in a raid against Kujawy; ${ }^{68}$ in 1271-1272 they were allies of Duke Vladimir of Volhynia; ${ }^{69}$ and led by Skomantas, the Yatvingians and the Rus'ians dependent on Lithuania fought in Kulm. ${ }^{70}$ One more part of the Yatvingians joined the Prussians in their struggle against the Order 1273-1274. ${ }^{71}$ Uncoordinated actions of the Yatvingians is to be treated as a consequence of their fragmentation. It is natural that some of them were ready to accept the rule of Christian dukes: the 1272 treaty of southern Yatvingians with the dukes of HaliczVolhynia possibly was a sort of declaration of the subordination to the Rus'ians that became evident in $1279 .{ }^{72}$

During Traidenis' rule (between 1268 and 1282) it became quite clear that the dynamics of relations with the Yatvingians were conditioned by a subjective position of the Lithuanian ruler rather than by the common Baltic interest. For quite a long time attention to Yatvingian matters on the part of the Lithuanian ruler cannot be observed with the exception of the joint campaign against Kujawy in 1269. But is could be simply a marauding raid, having nothing to do

${ }^{67}$ Regesta Lithuaniae, vol. 1, comp. H. Paszkiewicz (Warsaw, 1930), no. 433; Idem, Jagiellonowie a Moskwa, pp. 115-116; Włodarski, 'Problem Jaćwiński', p. 33; Powierski, 'Rola Jaćwieży', pp. 103-104.

68 Joannis Dlugosii Annales, p. 163. This raid is considered an anti-Order foray, cf. Powierski, 'Rola Jaćwieży' p. 104; Błaszczyk, Dzieje stosunków, p. 45, the latter's opinion is more considerate.

${ }^{69}$ Paszkiewicz, Jagiellonowie a Moskwa, pp. 129-130. He amends the date (1273, proposed by the HVL and coinciding with other Polish sources) to the year 1271, cf. Hrushevs'kyi, 'Khronol'ogiia', p. 48. The author of this article was also misled by this work, see, Dubonis, 'Meile ir politika', p. 32.

70 PD, p. 128 (§ 166(161)); PŽK, pp. 184-185, 397 (Batūra’s comments); Paszkiewicz, Jagiellonowie a Moskwa, p. 130; Powierski, 'Rola Jaćwieży', p. 104.

${ }^{71}$ PD, p. 131 (§ 173-174(168-169)); PŽK, pp. 189, 398 (Batūra’s comments); Gudavičius, Kryžiaus karai, p. 154.

${ }^{72}$ HVL, p. 131: four Yatvingian noblemen came to the duke Lev of Halicz, and to Dukes Vladimir and Mstislav of Volhynia asking for peace; and they got it and were glad of it. In 1279 some Yatvingians, suffering from hunger, asked Duke Vladimir to sell them grain. They acknowledged Volhynia's dominion and called its duke господине княже Володимере, see, HVL, p. 134; Dubonis, 'Meile ir politika', p. 33 (note 74). 
with Traidenis' intentions. ${ }^{73}$ Paszkiewicz presented one more indication of the Lithuanian-Yatvingian alliance. In 1273 The Lithuanians and the Yatvingians attacked the region of Lublin, and consequently Dukes Leszek and Konrad of Kujawy and Mazovia wreaked vengeance on the lands of the Yatvingians (Polesitarum) and the Prussians. However, according to Długosz's recent editors, such events could have not taken place in $1273 .{ }^{74}$ The Rus'ians subject to Lithuania might not have necessarily participated in the Skomantas-led Yatvingian campaign against Kulm in 1272-1273, either. ${ }^{75}$ They could have been subject Halicz and Volhynia, since at that time, as has been already noted, a part of the Yatvingians were inclined to give in to Rus'ian dukes. In 1274 occupying Drohychin and involving himself in a threeyear war with the dukes of Halicz and Volhynia Traidenis sought other aims instead of saving the Yatvingians. ${ }^{76}$

Soon the situation changed slightly. In 1227 the Lithuanians and the Yatvingians led by Skomantas marched to Poland at the same time striking a blow to the Teutonic Order - the Lithuanians separately conquered the lands of Brześć Kujawski, Łęczyca and Dobrzyń, and the Yatvingians attacked Kulm; the latter were supported by a strong Lithuanian force. ${ }^{77}$ The joint Sudovian (Yatvingian) and Lithuanian army that attacked Samland in 1281 was led by the Semigallian duke Nameisis, a subject of Traidenis. ${ }^{78}$ It would not be a mistake to state

${ }^{73}$ For Powierski the raid seemed anti-Crusader, see note 68 .

${ }^{74}$ Paszkiewicz, Jagiellonowie a Moskwa, p. 132; Joannis Dlugosii Annales, pp. 183-184, 358 (comment of Długosz's publishers); Długosz, Roczniki czyli Kroniki sławnego królestwa Polskiego, 7, 8 (Warsaw, 1974), pp. 232-234.

${ }^{75}$ See note 70.

76 Dubonis, 'Meile ir politika', pp. 32-33. The issue of Yatvingian security is accentuated in the activity of the Lithuanian sovereign: Paszkiewicz, Jagiellonowie a Moskwa, p. 130; Powierski, 'Rola Jaćwieży', p. 105.

${ }^{77}$ PD, pp. 136-137 (§ 192(187)) (on Skomantas); p. 138 (§ 195 (190)) (on Lithuanians in Poland); from the group of the chronicles of Poland Minorin the chronicles of Traska and Poland Minor, see Monumenta Poloniae historica (Pomniki dziejowe Polski), vol. 2 (Lvov, 1872), p. 843; vol. 3 (Lvov, 1878), p. 176; Gudavičius, Kryžiaus karai, p. 163; J. Powierski, 'Polityczne tło małżeństwa Bołesława II Mazowieckiego z córką Trojdena Litewskiego Gaudemundą Zofią’, Europa Środkowa $i$ Wschodnia w Polityce Piastów, ed. K. Zelinska-Melkowska (Torun, 1997), pp. 66-67.

${ }^{78} \mathrm{PD}$, p. $140(\S 204(199))$. Nameisis as a military leader is characterised in the Livonian Rhymed Chronicle (RLC), p. 334 (11. 9668-9672): 'Afterwards, when autumn came / Lithuanian troops / Were sent to Prussia / King Traidenis sent them / They were led by Nameisis'. Some researchers maintain that Peter of Dusburg and the LRC refer to different raids into Prussia: of $1279-1280$ and of 1281 , see Paszkiewicz, Jagiellonowie a Moskwa, p. 139. A reliable dating (1281) is proposed by Gudavičius, Kryžiaus karai, pp. 164-165. 
that joint campaigns of 1277 and 1281 were organised by Traidenis because in both cases they were conducted by an excellent military leader. In this case one can already detect easily cooperation between the Lithuanian monarch and leading representatives of the Yatvingian nobility, a cooperation not observed previously in the sources. Closer contacts between the two parties appeared in the aftermath of the Order's conquest of the Yatvingians begun in $1277-1278 .{ }^{79}$ Thus, in Lithuania this problem was dealt with seriously only when the Crusaders began their direct attacks on Sudovia (Yatvingians); nevertheless, the support of the Lithuanian sovereign to the Yatvingians was insignificant in comparison to his dynamic intensive military and political relations with other neighbours. ${ }^{80}$ Speaking about the defensive wars of 1277-1283, Peter of Dusburg does not at all mention direct Lithuanian support for the Yatvingians with the exception of the settlement of refugees in Lithuania (early in 1279 Traidenis directed his brother Sirputis and his Lithuanian-Yatvingian army to no other place but the land of Lublin; these Yatvingians possibly were from the former refugees in Lithuania ${ }^{81}$ ). Among them was Skomantas, a noble leader, directly submitting to Traidenis' authority like the Semigallian Nameisis. His links with Traidenis were tenuous, since after the death of the Lithuanian monarch he fled Lithuania and even brought the Order's army to Grodno in 1284. He was forced to leave Lithuania due to the new ruler's enmity to his predecessor Traidenis and his noblemen (barons). ${ }^{82}$

${ }^{79}$ PD, pp. $137-138$ (§ 193-194(188-189)), p. 139 (§ 197-198(192-193)), p. 140 (§ 202(197)), p. $141(\S 205(200))$, p. $141(\S 207(202))$, p. $142(\S 209(204))$, p. 143 (§ 211-212(206-207)), pp. 145-146 (§ 217-219(212-214)), p. 147 (§ 223(218)); Gudavičius, Kryžiaus karai, pp. 162-164.

${ }^{80}$ See the above-cited Jasas' remarks at the beginning of the article and note 1; M. Powierski, 'Rola Jaćwieży', pp. 104-105; in the lands of Halicz-Volhynia Traidenis was extremely active since his coming to power, see A. Dubonis, 'Lietuva po karaliaus Mindaugo mirties: kova dèl sosto 1264-1268 m.', Istorijos akiračiai. Skiriama profesoriaus habilituoto daktaro Antano Tylos 75-mečiui, ed. E. Rimša et al. (Vilnius, 2004), pp. 72-73; Dubonis, 'Meilè ir politika', pp. 31-35.

${ }^{81}$ Dubonis, 'Meilè ir politika', p. 33 (note 74).

82 The Sudovian Skomantas leaves the Order and retreats to Rus', see, PD, p. $143(\S 211(206))$. However, his traces are detected at Leipalingis, Lithuania, see V. Vaitkevičius remarks in Merkinès istorijos bruožai, ed. A. Černiauskas et al. (Vilnius, 2004), p. 99. Skomantas flees Lithuania, see PD, p. 147 (§ 223(218)); Dubonis, 'Pirmieji Lietuvos valdovai: Giminiška meile ir mirtina neapykanta', Lituanistica, 2, 2003, p. 9. Skomantas could leave Lithuania due to internal quarrels concerning Treniota's successor - such a cause of the submission of the famous Yatvingian to the Order among other reasons is presented by Powierski, 'Rola Jaćwieży', p. 109. 
Tensions in the relations between the Lithuanian monarch and the Yatvingian nobility were not defused easily even in the face of a most serious danger for some of them. The Yatvingians, like Skomantas, did not always opt for the variant of Lithuanian aid in difficult situations. Therefore, for a part of the Yatvingian nobility the fight against the Order did not turn into a matter of life and death since there were alternatives to Lithuania depending on the geographical situation. The Polexiani were ready for a peaceful baptism and submission to duke Casimir or sought refuge from the Order somewhere else in Poland ${ }^{83}$ others acknowledged the authority of the dukes of Halicz and Volhynia, still others accepted enforced Christianity from the Order, and still others joined Lithuania. Finally there was one more chance, exemplified by Skomantas' behaviour lurching from Lithuania to the Order. Thus there was no common Baltic interest defined by common linguistic, cultural, economic and other constituents; instead there was a clear social position conditioned by the estate interests of the Yatvingian nobility.

Traidenis could not negotiate with the Yatvingians because of their disunity. He conducted Lithuanian foreign policy as the Lithuanian monarch, but not as a noble leader of a major tribal aggregate, and he could hardly present the political aims that he set himself. The character of his relationship with the Yatvingians corresponded to the then political reality and traditions inherited from his forebears, and that restricted his support for the Yatvingians in their struggle.

Traidenis attitude to the fight of the Yatvingians and other Balts with the Crusaders could hardly be criticised for the loss of a strategic way of thinking. Ruling Lithuania at a particularly difficult time, he was not politically blind. Crucially important for him was the situation in the north and the relations with the Livonian Order, which as early as 1245 was charged with conquering Lithuania (and it attempted that diligently ${ }^{84}$ ) In the south - in Halicz-Volhynia the Tatars had been posing major threats to Lithuania periodically since 1258 . The Teutonic Order was not a priority in the Lithuanian foreign policy for a long time. ${ }^{85}$ In fact, Traidenis followed not the militant

${ }^{83}$ Ibid., p. 110; Yatvingian emigration to some other Polish dukedom is rejected by Włodarski, 'Problem jaćwiński', p. 33.

${ }^{84}$ Gudavičius accurately commented emperor Friedrich II's privilege issued to the Teutonic Order on occupying the lands of Curonia, Lithuania and Semigallia, see Mindaugo knyga, pp. 55-57, no. 23; Gudavičius, Kryžiaus karai, pp. 90-91.

${ }^{85}$ Gudavičius, Kryžiaus karai, p. 162; E. Gudavičius, Lietuvos istorija, vol. 1 (Vilnius, 1999), p. 71. 
policy of Treniota but a more flexible policy of Mindaugas in which Yatvingian matters were less pressing. Traidenis consciously evaded one more inopportune war against the Crusaders in Prussia and Sudovia, the approach of which to Lithuania he simply could not help seeing. He clearly avoided direct confrontation with the Order in Prussia and began open warfare only at the end of this rule. Prussian and Yatvingian resistance protected Lithuania. On the other hand, the Prussians, Semigallians, and Yatvingians, experiencing an unending onslaught of the Crusaders, sought Traidenis' protection and dispelled his doubts about the inevitability of armed opposition to the Order.

Traidenis was not inactive with respect to the Teutonic Order, but close to his realm he had political partners stronger than the Yatvingians. He valued his friendship with Duke Lev Danilovich of Halicz. That enabled him to live in peace with the Tatar war leader Nogai and to establish dynastic ties with the family of the Mazovian dukes by marrying his daughter off to Bolesław II, the younger of the two brothers. ${ }^{86}$ The Treaty of Raciąż (1254) establishing cooperation between Halicz-Volhynia and Mazovia was very inconvenient for the Lithuanian ruler at one time. Taking into consideration that the Lithuanian ruler did not maintain any political contacts with the Order, but at the same time acquired friends in its neighbourhood, one can state Traidenis' success by limiting the Order's chances to conclude treaties with Rus'ian and some Polish dukes due to Lithuania rather than the Yatvingians.

Translation: Alfonsas Laučka

\section{Author Details}

Dr Artūras Dubonis is Head of the Department of Palaeography, Lithuanian Institute of History. His special interests are the sources of Lithuanian history of the 15th and 16th centuries (especially the Lithuanian Metrica) and the history of Lithuanian society in the 13 th-16th centuries. He has published a monograph on the state structure of mediaeval Lithuania and several scores of articles on social and economic issues and foreign policy of Lithuania.

Address: Department of Palaeography, Lithuanian Institute of History, Kražių 5, LT-01108 Vilnius, Lithuania

Email: dubonis@istorija.lt

${ }^{86}$ Dubonis, 'Meile ir politika', pp. 33-34. 


\title{
JOTVINGIAI LIETUVIŲ ANTIKRYŽIUOTIŠKOS ORIENTACIJOS GENEZĖJE
}

\author{
Santrauka
}

\section{ARTÜRAS DUBONIS}

Remiantis išlikusiais skurdžiais Sūduvos (jotvingių) praeities šaltiniais, nesunku išskirti kelis reikšmingiausius jotvingiu ir lietuvių santykių epizodus, kurie atskleidžia gerokai painesnę, nei galima tikètis, jotvingių ir lietuvių politinio bendravimo paradigmą.

Konkrečių duomenų apie lietuvių ir jotvingių bendradarbiavimą iki $1243 \mathrm{~m}$. nèra. Iki XIII a. penktojo dešimtmečio pradžios Mindaugas laikèsi taikos su Voluinès ir Haličo kunigaikščiu Danilu irjam nerūpejjo jotvingiai.

Mindaugui pradejjus konsoliduoti savo valdžią Lietuvoje lietuvių „nedèmesingumas“ jotvingiams baigèsi. XIII a. penktojo dešimtmečio pradžioje Mindaugas iš nominalaus darèsi realiu dalies Sūduvos (jotvingių) - nèra abejonių, kad šiaurès rytų valdovu. Tačiau tarp Mindaugo ir jotvingių $1246 \mathrm{~m}$. kilusi nesantaika truko beveik visą Mindaugo valdymo laikotarpị ir tai lèmè milžiniškas Lietuvos karaliaus daromas nuolaidas Vokiečių ordinui Sūduvoje. Didesnę patirtį turinčių politinių veikëjų - Vokiečių ordino, pirmojo rusų karaliaus Danilo ir Mazovijos kunigaikščio Siemovito - darnios veiklos rezultatas buvo jotvingių žemių dalybos $1254 \mathrm{~m}$. Racionže. Net karalius Mindaugas jiems padèjo kariauti pietų Jotuvoje, netiesiogiai prisijungdamas prie Racionžo susitarimų.

Kai Treniota karo su krikščionimis reikalus $1261 \mathrm{~m}$. perėmė i savo rankas, aktyvèjo jotvingių (ir prūsų) kova su kryžiuočiais, iškilo ryškus jų karo vadas Skomantas, vèliau pasižymejęs prolietuviška laikysena. Tai rimti ženklai, kad Lietuva pradeda padèti jotvingiams. Vis dèlto rimtesnès lietuviu pagalbos jotvingiai ir prūsai dažniau nesulaukdavo. Akivaizdu, kad lietuviai ir jotvingiai iki Treniotos žūties $1264 \mathrm{~m}$. bendradarbiavo, bet istoriografijoje paplitęs teiginys apie jotvingiu (su iprasta išlyga „dalies jotvingiư“) prisijungimą prie Mindaugo monarchijos nèra pagristas rimtais argumentais.

Traideniui valdant Lietuvą 1268-1282 m. pradžioje galutinai paaiškejja, kad santykių su jotvingiais pobūdi diktuoja subjektyvi lietuvių valdovo pozicija. Iki $1277 \mathrm{~m}$. lietuviu valdovo domejjimosi jotvingių reikalais nepastebime. Traidenis užsienio politiką tvarkè kaip Lietuvos monarchas, o ne kilmingas didesnio genčiu junginio vadas, negalintis dorai išvardyti savo politinių tikslų. Jo santykių su jotvingiais forma atitiko susidariusias politines realijas ir pirmtakų, pirmiausia Mindaugo, padiktuotas tradicijas - visa tai varžè lietuvių monarcho paramą jotvingiu kovai, nors Vokiečių ordino karo mašina nepaliaujamai artèjo prie Lietuvos sienu.

Traidenis nebuvo visiškai neveiklus Vokiečių ordino atžvilgiu, bet toje savo valstybės pašonėje jis turèjo stipresnių už jotvingius politinių partnerių. Draugyste su Haličo kunigaikščiu Levu Danilovičiumi jam padejjo išsaugoti taiką su totoriu karvedžiu Nogajumi ir užmegzti dinastinius ryšius su Mazovijos kunigaikščiu šeima už jaunesniojo iš dviejų broliu, Boleslovo II, ištekino dukrą. Haličo-Voluinès, Mazovijos ir Ordino bendradarbiavimas pagal Racionžo sutarties $(1254 \mathrm{~m}$.) schemą Lietuvos valdovui vienu metu buvo labai neparankus. Turint omeny tai, kad Lietuvos valdovas nepalaike jokių politinių kontaktų su Ordinu, bet jo kaimynystejje igijo draugu, galima konstatuoti, kad Traideniui pavyko maksimaliai apriboti Vokiečių ordino vyresnybès galimybes susiderèti su rusų ir kai kurių lenkų žemių kunigaikščiais, tik jau ne jotvingių, o Lietuvos valstybės sąskaita. 